\title{
The Role of Taboos in the Protection and Recovery of Sea Turtles
}

\author{
LoriKim Alexander ${ }^{1}$, Andrews Agyekumhene ${ }^{2}$ and Phil Allman ${ }^{1 *}$ \\ ${ }^{1}$ Department of Biological Sciences, Florida Gulf Coast University, Fort Myers, FL, United States, ${ }^{2}$ Wildlife Division, Forestry \\ Commission, Winneba, Ghana
}

Despite increased efforts from government agencies, scientists, and non-government organizations over the past few decades, anthropogenic sources of sea turtle mortality continue to threaten the survivorship of sea turtle species around the globe. More recent efforts to engage local people with community-based sea turtle conservation programs have been based primarily on economic incentives and less on cultural and social traditions. But there is growing evidence that informal institutions such as, taboos can be extremely effective at promoting wildlife conservation. Ghana is a culturally diverse country where local traditions have shown to improve protection for primates, crocodiles, and many bird species. This study explores the presence of a sea turtle taboo in fishing communities to demonstrate that traditional practices make residents more receptive to sea turtle conservation and more willing to follow government regulations. Fishers in the

OPEN ACCESS

Edited by:

Mariana M. P. B. Fuentes,

Florida State University, United States

Reviewed by:

Rochelle Diane Seitz,

Virginia Institute of Marine Science,

United States

Manjula Tiwari,

Southwest Fisheries Science Center

(NOAA), United States

*Correspondence:

Phil Allman

pallman@fgcu.edu

Specialty section:

This article was submitted to Marine Conservation and

Sustainability,

a section of the journal

Frontiers in Marine Science

Received: 31 March 2017

Accepted: 14 July 2017

Published: 02 August 2017

Citation:

Alexander L, Agyekumhene A and Allman P (2017) The Role of Taboos in the Protection and Recovery of Sea

Turtles. Front. Mar. Sci. 4:237.

doi: 10.3389/fmars.2017.00237 communities that are aware of the taboo are also more willing to adjust fishing methods to better protect sea turtles. The traditional taboo and national laws appear to be working synergistically to enhance sea turtle conservation in some regions of Ghana. This paper extends the argument that sea turtle conservation strategies succeed when the cultural and social traditions of local communities are integrated with management activities.

Keywords: sea turtles, social taboos, conservation, biodiversity, Ghana, Africa

\section{INTRODUCTION}

Sea turtle conservation efforts around the world have historically incorporated the interests and views of local people. Such community-based conservation (CBC) programs take on a variety of forms, from indirect engagement to the implementation of community-driven conservation goals that prioritize sustainable resource use (Western, 1994). Despite the increasing popularity of $\mathrm{CBC}$ approaches in conservation biology, success in achieving recovery outcomes has been mixed (Western and Wright, 1994; Kellert et al., 2000). This is because the effectiveness of CBC is influenced by the program's ability to integrate cultural components, and adjust action plans according to shared values of the community (McShane and Wells, 2004; Peterson et al., 2010).

Taboos and cultural laws are social institutions that govern behavior within communities. The term "taboo" is derived from the Polynesian term "tabu," which means "forbidden." Taboos regulate the way people interact with the world around them by prohibiting the use of items considered sacred. All human societies ascribe to some form of social taboo that is maintained as an informal institution by the cultural standards of its members (Colding and Folke, 2001; Negi, 2010). Unlike judicial law and other types of formal institutions, taboos represent unwritten social rules that regulate behavior in humans that are bound together by common obligations to each person and a shared reverence for the sacred (Freud, 1913). Informal institutions such as, taboos are based on cultural norms that do not require government intervention for proliferation or enforcement (Posner and Rasmusen, 1999). 
The role social institutions have in conservation biology has recently attracted more global attention (Colding and Folke, 2001; Riley, 2010), with a growing amount of literature demonstrating taboos improve conservation efforts and resource management (e.g., Uyeda et al., 2014). Tengo et al. (2007) found that adherence to taboos against desecration of sacred forests in Madagascar was influential in maintaining the ecological value of the area. In Indonesia, a taboo held by the To Lindu people affords protection to Tonkean macaques, Macaca tonkeana, despite damage to local crops caused by the monkeys (Riley, 2010).

Before the introduction of Western conservation methods to Africa, many communities already had established resource management systems based on complex religious and cultural belief systems that incorporate myths, taboos, totems, and social norms (Ostrom, 1990; Hulme and Murphree, 1999; Roe et al., 2009). These systems originated to protect and promote communal wellbeing, rather than individual interest or that of preserving wildlife (Kideghesho, 2008). In Nigeria for instance, each of the communities surrounding Cross River National Park maintains a sacred forest that protects many species of wildlife, but as Jimoh et al. (2012) reports, the forests are protected for spiritual reasons not directly associated with conservation interests. A sacred grove between Boabeng and Fiema in central Ghana provides a sanctuary for Campbell's guenon, Cercopithecus campbelli, and ursine colobus, Collubus vellerosus (Wong and Sicotte, 2006; Arhin, 2008). These species are protected from hunting through an oral tradition that describes the monkeys as children of the gods Daworo and Abodwo. Although declining across their range, the increasing population of $C$. vellerosus in this forest is attributed to the taboo that protects them from hunters (Saj et al., 2006). As observed on a global scale, informal institutions in Africa can thus assist conservation efforts in cases where the cultural norms and community behaviors align with the management goals, even in situations when the norms originated for other reasons.

In Ghana, indigenous belief systems have played significant roles in the management of natural resources (Abayie-Boaten, 1998). Ntiamoa-Baidu (1991) identified taboos and totems as the key indigenous methods for conserving biodiversity in Ghana. The West African crocodile, Crocodylus suchus, is protected and held sacred by the Tongo-Tengzuk communities of northern Ghana (Arhin, 2008). The crocodiles are protected through a belief that the crocodiles are the incarnation of their important ancestors. This species is therefore abundant in ponds surrounding these communities (Shirley et al., 2009). The Sankana community in northern Ghana serves as a sanctuary for pythons and frogs because community members consider it taboo to consume them (Diawuo and Issifu, 2015). According to oral tradition, the community had to cross a river to escape frequent attacks by slave raiders. A log in the river was used to help cross, but then turned into a python after everyone was safely across. Frogs are also protected because the community believes a frog once led their ancestors to a water source. Moreover, many communities throughout Ghana have sacred groves that serve to protect the area's animal and plant biodiversity (Campbell, 2005).
Informal institutions have historically afforded protection to sea turtles in many cultures around the planet. Pacific islanders throughout Polynesia revere sea turtles as sacred and, therefore, forbid the eating or capture of some species to certain clans or casts (Johannes, 1978; Morgan, 2007), and special rites-ofpassage ceremonies (Woodrum, 2010). The fishing community of Buzios Island, Brazil prohibits the consumption of turtle meat as a means of protecting sea turtles. The community restricts captures to only what is necessary for traditional medicine (Begossi, 1992).

Sea turtles are a group of highly migratory species that live primarily in tropical and temperate oceans. They serve keystone functions that collectively maintain healthy and diverse seagrass bed, coral reef, and beach dune habitats (Meylan, 1988; Bouchard and Bjorndal, 2000; Leon and Bjorndal, 2002; Bjorndal and Jackson, 2003). Sea turtles also help maintain a balanced trophic structure that benefits commercially valuable fish species (Houghton et al., 2006; Lynam et al., 2006). Five of the world's seven sea turtle species occur along the western coast of Africa, and at least four species currently nest in Ghana (Allman and Armah, 2008; Allman et al., 2015). The five species that occur in Ghana are the leatherback (Dermochelys coriacea), olive ridley (Lepidochelys olivacea), green (Chelonia mydas), loggerhead (Caretta caretta), and hawksbill (Eretmochelys imbricate; Allman and Armah, 2008). Each of these species has suffered significant population declines and is currently listed on the IUCN Red List of species threatened with extinction (www.iucnredlist.org). Ghana's Wildlife Conservation Regulation Bill (I.1 685) of 1,971 prohibits the capture or slaughter of sea turtles. Although enforcement is limited, those prosecuted serve time in jail and must pay a fine. Anthropogenic sources of mortality in Ghana include direct harvest of eggs and nesting females, accidental capture in near-shore and offshore fishing gear, and plastic pollution (Agyekumhene et al., 2010).

Ghana's coastal communities consider ocean and marine species to be a significant part of their identity and culture and, as such, there are social norms that influence their daily activities. Many fishing communities throughout Ghana recognize Tuesday to be the day of the sea-God and therefore do not fish (Armah et al., 1998). Furthermore, some community members tell a story that involves a fishing boat becoming lost at sea, but being saved by a sea turtle that directs the boat to shore. Other communities explain how sea turtles saved their ancestors from violent storms or slave ships. One variation explains how sea turtles helped the Dangme people of southeastern Ghana cross the Volta Estuary while retreating from an attacking Ashante army. This taboo originated in southeastern Ghana and has likely decreased the direct harvest of sea turtles since the community elders punish offenders (Armah et al., 1998).

The spiritual world in Ghana serves a significant function in wildlife conservation, and has likely influenced behaviors in Ghana's fishing communities. Fishers in Cape Coast, Ghana accepted a recent government fishing closure of the Fosu Lagoon because traditional practices already reduced fishing efforts in the lagoon. Through a set of taboos that give reverence to Nana Fosu, the God of the lagoon, the fishers understood 
the need for mangrove restoration to protect the nursery for fish that belong to Nana Fosu (Darkwa and Smardon, 2010).

This study documents a social taboo that serves to support official regulations that protect sea turtles in the water and on the nesting beaches of Ghana. We report interview data from three ethnic groups to explore local knowledge of sea turtles, knowledge of taboos and federal regulations, and their attitudes toward protecting sea turtles.

\section{METHODS}

\section{Study Sites}

Ghana is located in the western portion of the Gulf of Guinea and contains $535 \mathrm{~km}$ of coastline (Figure 1). Three ethnic groups populate the coastal region: Nzima in the west, Fante in the central region, and Dangme in the east (Gocking, 2005). For this study, we selected four fishing communities to investigate based on the following criteria: (1) proximity to a known sea turtle nesting beach, (2) minimum of one community within each ethnic group, (3) the presence of an artisanal fishery that utilizes purse seine nets, and (4) varied amounts of Ghana

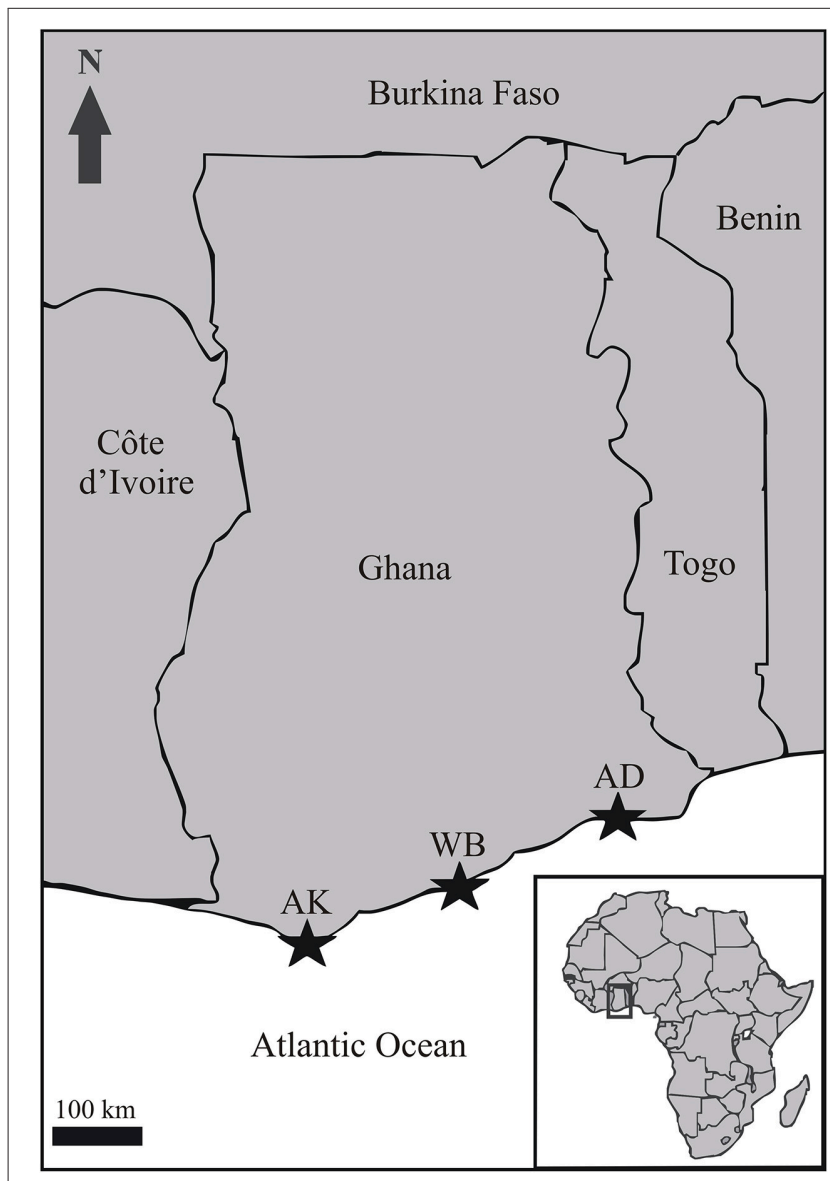

FIGURE 1 | Surveys were conducted in Akwidaa, Winneba, and two villages (Azizenya and Totope) on the Ada peninsula in Ghana, West Africa. AK, Akwidaa; WB, Winneba; AD, Ada.
Wildlife Division (GWD) sea turtle conservation efforts in the area.

\section{Community 1}

Akwidaa is situated at $4^{\circ} 45^{\prime} 0 \mathrm{~N}$ and $2^{\circ} 1^{\prime} 0 \mathrm{~W}$ in the southernmost district of Ahanta West in the Western region. The village is comprised of Nzima people from the original Akan ethnic group that migrated across the Sahara Desert in the eleventh century (Gocking, 2005). Eleven interviews were conducted on the beachfront of Akwidaa Old Town. A non-profit organization briefly conducted sea turtle surveys in this area during the 1990's, but the GWD has not been present. The foreign owner of an ecolodge near Akwidaa recently attempted to initiate a sea turtle conservation volunteer program, but this has not succeeded thus far.

\section{Community 2}

Winneba is located within the Central region at $5^{\circ} 19^{\prime} 60 \mathrm{~N}$ and $0^{\circ} 37^{\prime} 0 \mathrm{~W}$, and is the capital of the Effutu Municipal district. The Fante people of Winneba are also a subgroup of the Akan ethnic group that formed their own state in the fourteenth century (Gocking, 2005). The GWD has a field office here for the primary function of managing the Muni-Pomadze Ramsar site, a 9,461.12 hectares estuarine coastal wetland and lagoon adjacent to Winneba. Since 2011, the local GWD officers have conducted routine sea turtle education, ecotourism, and law enforcement activities in the area. Ten interviews were conducted on the beach in the primary fishing district of Winneba.

\section{Community 3 and 4}

Azizenya, at $5^{\circ} 46^{\prime} 0 \mathrm{~N}$ and $0^{\circ} 39^{\prime} 0 \mathrm{E}$, and Totope, at $5^{\circ} 46^{\prime} 60 \mathrm{~N}$ and $0^{\circ} 31^{\prime} 60 \mathrm{E}$, are found on the Ada peninsula within the Dangme East district of the Greater Accra region. Azizenya is roughly $8 \mathrm{~km}$ east of Totope and $1 \mathrm{~km}$ east of the larger township of Ada Foah. The GWD has maintained an office in Ada Foah to protect the Songor Lagoon Ramsar site since 1988. The GWD officers routinely conduct sea turtle education, ecotourism, and law enforcement activities in the area. The Dangme people of this region are known to revere the sea turtle as sacred and consider it taboo to harm or eat them (Armah et al., 1998). Ten interviews were conducted in each village, but these data are presented together due to the proximity and similar characteristics of the two villages.

\section{Data Collection}

We conducted interviews in each village between December 2010 and January 2011, with all interviews in a particular community being conducted on the same day. The semistructured interview design (Creswell, 2013) included questions related to fisher demographics, fishery design, knowledge of sea turtles, and sea turtle conservation. We followed a set order of questions that included open-ended questions and others that allowed participants to choose from a set of possible answers. Open-ended questions gave participants an opportunity to elaborate with examples from their own experiences. We presented photographs of six sea turtle species, a bottlenose dolphin (Tursiops truncates), a humpback whale (Megaptera 
novaengliae), and the North American gopher tortoise (Gopherus polyphemus) to learn which animals have been captured by their nets. Each interview took approximately $30 \mathrm{~min}$ to complete. Each interview was conducted with a Ghanaian translator and recorded with a digital voice recorder or video camera.

Fishers were selected for the study using non-probability convenience sampling and snowball sampling. We selected only fishers for this study because they have more direct interactions with sea turtles and are considered a primary stakeholder when promoting sea turtle conservation in the region. When possible, interviews were conducted on Tuesdays when fishers are more available since the taboo forbids fishing on this day. Volunteers and community members fluent in English and Ga, Twi, or Dangme conducted the surveys using local languages. Two individuals then translated each answer to English. Interviews were conducted simultaneously within each village to ensure each respondent fished on a different boat, and therefore acquiring independent samples. Although sample size per village is small, each fishing village utilizes between 12 and 20 boats so we are confident that our sample reflects the activities of the artisanal fishery in each village.

Each respondent was assured of their anonymity in participating in the project, and was asked to sign a consent form to verify their willingness to contribute. In exchange for participation, respondents were given a flag with an original sea turtle logo to fly on their boats. This was presented at the end of the interview so they were not aware of any forthcoming compensation. All activities followed procedures approved by Florida Gulf Coast University's Internal Review Board (IRB\#2010-59), and all research participants provided written and informed consent.

track2ptSix key informants from Ada Foah were also interviewed using open-ended questions that further explored the cultural traditions and beliefs surrounding sea turtles in the region. The key informants are community leaders within the traditional authority of the area. Key informants were not given an individual compensation, but school supplies, footballs, and clothes were donated to the chief of Ada and two nearby communities.

\section{Data Analysis}

All interviews were translated to English and coded per question. Descriptive statistics are presented to identify trends within, and among, fishing communities and to provide accounts of discrepancies across the research topics. Such approaches have proven useful for identifying trends using similar data structure
(Silverman, 2006; Schneller, 2008; Senko et al., 2011; Creswell, 2013).

\section{RESULTS}

Ghana's artisanal fishery primarily operates through the use of purse seine nets that are deployed from fishing boats in nearshore waters immediately adjacent to the crew's home fishing village. The crew is comprised of men who are often from the same family, or members of the community who are hired by the boat's owner. The catch is divided among the fishermen in proportions that are negotiated before each fishing trip. Most of the captured fish are sold to women in the community who will then sell the fish in local markets and restaurants. The fishers keep the remaining fish for consumption with their immediate family members.

Fishing is the primary occupation for $92 \%$ of all respondents, with only four individuals indicating they have alternative employment when not fishing (Table 1). Fishing experience ranged from $<1$ year to 60 years across all sites. Nearly $93 \%$ had 10 or more years of fishing experience and $68 \%$ had more than 20 years of experience. Half of the fishers (Akwidaa $=46 \%$; Winneba $=60 \%$; Ada $=47 \%$ ) own the vessel on which they work, others serve as a member of the crew. All respondents in Winneba and Ada have family members who fish, yet in Akwidaa those with fishers in the family are a minority (9\%).

\section{The Fishery}

track2ptA large majority of fishers ( $84 \%$ across sites) believe their catch has decreased over the years because of a reduction in fish populations across the region. When asked, many reasons were given for the decline, but the presence of too many boats and the illegal use of lights when night fishing were considered the primary causes (Figure 2). Interestingly, 18\% (6/34) of fishers attributed the decline to non-anthropogenic causes such as, natural fluctuations, God, and weather conditions. Furthermore $50 \%$ of all fishers (Akwidaa $=100 \%$, Winneba $=44 \%$, Ada $=$ $27 \%$ ) accused sea turtles as a reason for the reduction in fish catch (Table 3).

Most individuals (85\%) acknowledged they catch sea turtles when fishing, but most were quick to add that it was not intentional (Table 2). We could not determine weekly by-catch rates as several fishers noted that catching a sea turtle was rare, with an occurrence rate of 1-3 months, or even 2 years. Fifteen percent across all sites reported catching sea turtles on every fishing trip, but personal experience (Agyekumhene and Allman) indicates it is very unlikely any artisanal fishing vessel would

TABLE 1 | Demography of fishers selected for participation in the study.

\begin{tabular}{|c|c|c|c|c|c|c|}
\hline Location & Ethnic group & Number surveyed & Fishing is primary occupation & Years of fishing experience & Boat owner & Family members also fish \\
\hline Akwidaa & Nzima & 11 & 10/11 (91\%) & $23.5 \pm 5.0(6-50)$ & $5 / 11(46 \%)$ & $1 / 11(9 \%)$ \\
\hline Winneba & Fante & 10 & $10 / 10$ (100\%) & $19 \pm 3.2(0-38)$ & $6 / 10(60 \%)$ & $10 / 10(100 \%)$ \\
\hline Ada & Dangme & 20 & 16/19 (84\%) & $30.5 \pm 3.0(11-0)$ & $9 / 19$ (47\%) & $19 / 19$ (100\%) \\
\hline Overall & & 41 & $36 / 40(90 \%)$ & $30.5(0-60)$ & $20 / 40$ (50\%) & $30 / 40(75 \%)$ \\
\hline
\end{tabular}




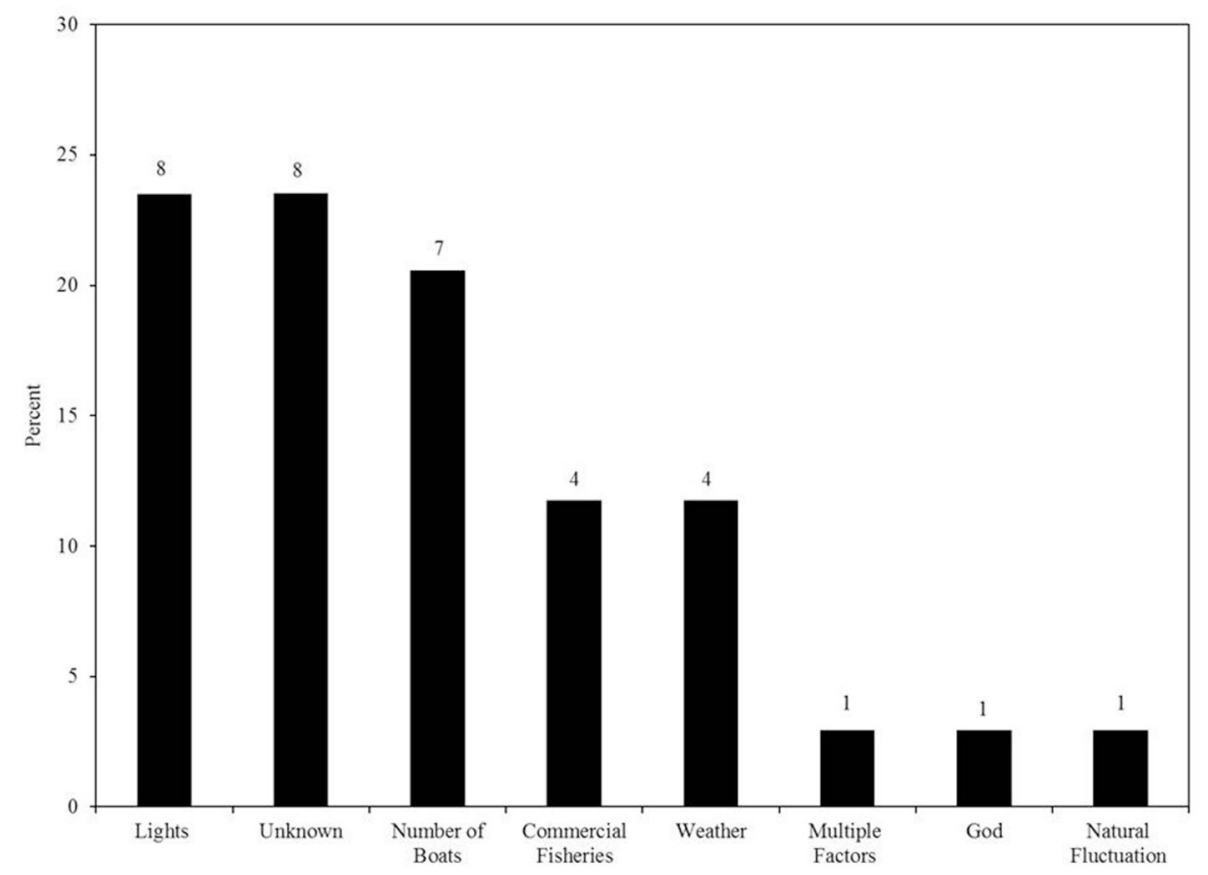

FIGURE 2 | The frequency of responses given by fishers to explain why they have observed a decrease in fish catch over recent years. Data are presented across all sites included in the study.

TABLE 2 | Responses from fishers when asked questions regarding their experiences with sea turtle captures in the artisanal fisheries of three communities in Ghana.

\begin{tabular}{|c|c|c|c|c|c|c|c|}
\hline Location & $\begin{array}{l}\text { Catch sea } \\
\text { turtles }\end{array}$ & $\begin{array}{l}\text { Release captured } \\
\text { sea turtles }\end{array}$ & $\begin{array}{c}\text { Captured sea turtles } \\
\text { are eaten }\end{array}$ & $\begin{array}{l}\text { Captured sea turtles } \\
\text { are sold }\end{array}$ & $\begin{array}{l}\text { Captured sea turtles } \\
\text { are eaten and sold }\end{array}$ & $\begin{array}{c}\text { Sea turtles } \\
\text { captured all year }\end{array}$ & $\begin{array}{l}\text { Sea turtles } \\
\text { reduce fish catch }\end{array}$ \\
\hline Akwidaa & 9/11 (82\%) & 7/9 (78\%) & 2/6 (33\%) & 2/9 (22\%) & 1/6 (17\%) & 1/6 (17\%) & 8/8 (100\%) \\
\hline Winneba & 8/10 (80\%) & 6/9 (67\%) & 2/8 (25\%) & 3/9 (33\%) & 4/8 (50\%) & 0/9 (0\%) & 4/9 (44\%) \\
\hline Ada & 18/20 (90\%) & 15/16 (94\%) & 1/13 (8\%) & 0/13 (0\%) & 0/13 (0\%) & 1/16 (6\%) & 4/15 (27\%) \\
\hline Overall & $35 / 41$ (85\%) & 28/34 (82\%) & $5 / 27$ (19\%) & $5 / 31(16 \%)$ & $5 / 27$ (19\%) & 2/31 (7\%) & 16/32 (50\%) \\
\hline
\end{tabular}

TABLE 3 | Frequency of fishers that reported capturing different species of sea turtles in the artisanal fishery.

\begin{tabular}{|c|c|c|c|c|c|c|c|c|c|c|c|c|c|c|c|}
\hline \multirow[t]{2}{*}{ Location } & \multicolumn{3}{|c|}{ Leatherback } & \multicolumn{3}{|c|}{ Olive Ridley } & \multicolumn{3}{|c|}{ Green } & \multicolumn{3}{|c|}{ Loggerhead } & \multicolumn{3}{|c|}{ Hawksbill } \\
\hline & DK & No & Yes & DK & No & Yes & DK & No & Yes & DK & No & Yes & DK & No & Yes \\
\hline Akwidaa & 0.00 & 0.25 & 0.75 & 0.00 & 0.33 & 0.67 & 0.00 & 0.25 & 0.75 & 0.00 & 0.33 & 0.67 & 0.00 & 0.33 & 0.66 \\
\hline Winneba & 0.00 & 0.37 & 0.63 & 0.11 & 0.11 & 0.78 & 0.00 & 0.22 & 0.78 & 0.00 & 0.22 & 0.78 & 0.10 & 0.45 & 0.45 \\
\hline Ada & 0.00 & 0.25 & 0.75 & 0.00 & 0.25 & 0.75 & 0.00 & 0.16 & 0.84 & 0.11 & 0.33 & 0.56 & 0.12 & 0.24 & 0.64 \\
\hline
\end{tabular}

DK, Do Not Know.

catch a turtle on each fishing trip. Interestingly, 29 fishers (93\%) indicated sea turtles are not captured year-round, but only during the dry or "Christmas" season.

Only one individual in Ada indicated a captured sea turtle is either eaten or sold (or both), as opposed to 12 fishers that indicated they are not eaten or sold. Fifteen respondents (94\%) from Ada indicated they release live sea turtles when captured. Comparing sites, a lower portion of fishers in Akwidaa (78\%) and Winneba (67\%) return captured turtles to the sea, and a higher percentage eat or sell them (Table 2).

\section{Sea Turtle Knowledge, Conservation and Taboo}

The fishers were able to identify sea turtles, but they roughly classify leatherbacks as a "large turtle" and all other species as "small turtles". When shown photographs of each species, fishers could identify different species they have encountered. Most fishers reported catching leatherbacks, olive ridleys, and green turtles, with incidence rates of $75-80 \%$ across sites (Table 3). Over 50\% indicated they have captured loggerheads and hawksbills, although these two species do not routinely nest 
in Ghana. Four individuals indicated they have captured gopher tortoises in their nets (Table 4). Ghana's coastal zone is home to three species of hingeback tortoises (Kinixys sp.), so it is possible the fishers have encountered a tortoise near the beach. Sixty-five percent of respondents indicate they have captured a dolphin, whereas 55\% reported catching a whale (Table 4). Dolphins are present in Ghana but rarely seen, and humpback whales migrate through Ghana from September through November each year.

Across all sites, 33 of 34 respondents (97\%) asserted that their communities protect sea turtles, but not all relate it to the existence of a taboo (Table 5). This protection is manifested by helping hatchlings into the sea, sometimes releasing turtles captured in fishing nets, or alerting authorities about poaching activity. None of the fishers in Akwidda acknowledged a taboo, story, or any other traditional custom that would afford protection to sea turtles, but they were quick to say their community is now protecting turtles because the eco-lodge owner instructed them to. Almost 50\% (44\%) of the respondents in Winneba are aware of a taboo regarding sea turtles, and therefore, does not harm them. In Ada, $88 \%$ of the respondents affirm a history of a taboo against harming sea turtles due to a cultural story that has been passed from generation to generation (Table 5). Key informants confirm the existence of an oral tradition and taboo against harming or eating sea turtles in the Ada area, but indicated that the influx of other clans and groups into the area results in more people not knowing the tradition or upholding the taboo. The key informants held that the traditional belief is verbally passed from elders to the younger generation. Further, many stated that the existence of this tradition has led to better receptivity of conservation efforts, namely the federal law.

The majority $(86 \%)$ of fishers in each village are aware that laws protect sea turtles from harm. Knowledge of the law is

TABLE 4 | Frequency of fishers that reported capturing a tortoise and marine mammals in the artisanal fishery.

\begin{tabular}{|c|c|c|c|c|c|c|c|c|c|}
\hline \multirow[t]{2}{*}{ Location } & \multicolumn{3}{|c|}{ Gopher tortoise } & \multicolumn{3}{|c|}{ Humpback whale } & \multicolumn{3}{|c|}{ Bottlenose dolphin } \\
\hline & DK & No & Yes & DK & No & Yes & DK & No & Yes \\
\hline Akwidaa & 0.00 & 0.87 & 0.13 & 0.00 & 0.38 & 0.62 & 0.00 & 0.50 & 0.50 \\
\hline Winneba & 0.00 & 0.87 & 0.13 & 0.00 & 0.67 & 0.33 & 0.11 & 0.22 & 0.67 \\
\hline Ada & 0.00 & 0.79 & 0.21 & 0.00 & 0.63 & 0.37 & 0.00 & 0.26 & 0.74 \\
\hline
\end{tabular}

DK, Do Not Know.

TABLE 5 | Frequency of respondents affirming community protection, a taboo, and knowledge of laws that protect sea turtles from harm in Ghana.

\begin{tabular}{lcccc}
\hline Location & $\begin{array}{c}\text { Community } \\
\text { protect sea } \\
\text { turtles }\end{array}$ & $\begin{array}{c}\text { Cultural story } \\
\text { regarding sea } \\
\text { turtles }\end{array}$ & $\begin{array}{c}\text { Knowledge of } \\
\text { law protecting } \\
\text { sea turtles }\end{array}$ & $\begin{array}{c}\text { Law } \\
\text { influence } \\
\text { fishing }\end{array}$ \\
\hline Akwidaa & $7 / 7(100 \%)$ & $0 / 8(0 \%)$ & $5 / 7(71 \%)$ & $1 / 3(33 \%)$ \\
Winneba & $7 / 8(88 \%)$ & $4 / 9(44 \%)$ & $7 / 9(78 \%)$ & $3 / 5(60 \%)$ \\
Ada & $19 / 19(100 \%)$ & $15 / 17(88 \%)$ & $18 / 19(95 \%)$ & $8 / 12(67 \%)$ \\
\hline Overall & $33 / 34(97 \%)$ & $19 / 34(56 \%)$ & $30 / 35(86 \%)$ & $12 / 20(60 \%)$
\end{tabular}

highest in Ada (95\%) and lowest in Akwidaa (71\%; Table 5). Thirty percent of the fishers know the penalty for breaking the law is arrest and $24 \%$ know that it is the GWD that enforces the law. Only $33 \%$ of respondents in Akwidaa stated the law influences their fishing methods. Most fishers in Winneba (60\%) and Ada (67\%) have made adjustments to their fishing methods because of the legal protection that served to validate the taboo that was already established in these communities.

\section{DISCUSSION}

The aim of this study was to explore the presence of a taboo protecting sea turtles, knowledge of federal laws, and willingness to protect sea turtles in Ghana. The interviews conducted among three ethnic groups demonstrate fishers routinely interact with sea turtles and are generally able to recognize different species. In communities where a taboo exists, and the GWD has a presence (Winneba and Ada), fishers are more knowledgeable and receptive to formal regulations that protect sea turtles. Although not directly tested, the protection of sea turtles in Winneba and Ada are likely driven by the taboo, instead of GWD presence, because sea turtle education programs and legal enforcement had not been conducted in Winneba prior to this study. More fishers in these two communities are willing to modify their fishing methods to reduce sea turtle by-catch and mortality. However, individuals in Winneba and Ada express concern about the erosion of cultural heritage due to modernization and immigration of individuals from ethnic groups that do not share the same cultural norms.

Fishing communities in Winneba and Ada observe the taboo protecting turtles, but it is noticeably absent in Akwidaa. The taboo appears to be strongest with the Dangme people of Ada where the story speaks of turtle saving their ancestors during a war with the Ashante. Fishers in Winneba understand the taboo as a cultural norm recognizing sea turtles for saving their fisher ancestors who were lost at sea. Winneba's location in central Ghana makes the town much more ethnically diverse than Ada, with individuals from clans that do not recognize the sea turtle taboo, but also from clans that do (Gocking, 2005). The Nzima fishers of Akwidaa are not aware of a taboo protecting turtles, and therefore are more likely to consume them when captured in nets or observed on the nesting beach.

All communities are aware of the laws protecting sea turtles regardless of whether the taboo is prevalent. Further, each community appears to protect sea turtles, or are at least willing to accept sea turtle conservation efforts. Ada had the highest percentage of respondents who were aware of the legal protection of sea turtles, and the most fishers in the area who adjust their fishing methods in response. Fishers in Ada and Winneba reported that turtles are still sometimes eaten and sold due to lost resources from the damaged net caused by incidentally catching a sea turtle. Therefore, recognition of the taboo does not necessarily result in adherence. Fishers in Ada and Winneba exhibit respect for sea turtles and the taboo, but admit to selling turtle meet to recover the cost of repairing their damaged nets. Some fishers do not consider this an infringement of the taboo since the turtles are captured incidentally. 
The overwhelming support for sea turtle conservation in Ada is likely a result of the cultural restriction influencing the fishers to better support the more recent legal protection that is now being enforced by the GWD. Furthermore, the GWD has routinely conducted sea turtle education programs in the Ada region for 20 years before this study. The strong support for sea turtle conservation in Winneba is likely a result of the diverse ethnic groups present in the community, and the constant rotation of fishers among the boats. The GWD office in Winneba only recently began sea turtle education and law enforcement programs. However, the community already had supported sea turtle conservation and had some awareness for the taboo. In contrast, fishers in Akwidaa are not regulated by a taboo or influenced by the GWD and therefore are less willing to adjust their fishing methods in ways that would decrease sea turtle captures. The community affirms an effort to protect sea turtles but this appears to be driven by directives from a British-owned eco-lodge adjacent to the community. The lodge owner requested the community to stop harvesting sea turtles on the beaches visited by the lodge's guests. In the absence of GWD officers in the area, the fishers' interest in sea turtle conservation was limited to requests made by the eco-lodge owners.

Ghana's sea turtle taboo has likely reduced mortality in some areas as sea turtle by-catch was reported by most respondents, but a significant number across all sites indicated that captured turtles are released from the net. The fishers advised that a catch is typically unintentional and not desirable. A captured sea turtle will significantly damage a net by tearing severe holes that are too expensive to repair. Such holes allow some fish to escape and may explain why many fishers remarked that sea turtles are responsible for the observed decrease in fish capture. Our survey questions did not allow us to adequately explore the rate of sea turtle capture, but most fishers indicated that catching a sea turtle is not common. Although a few fishers reported sea turtles are captured year-round, most reported that turtles are captured only during the dry season from November through May. This time period coincides with the primary sea turtle nesting season in Ghana, which suggests fishers may be capturing gravid females that migrate to Ghana for nesting purposes. If fishers are in fact capturing a disproportionally large number of gravid females, then even a small catch rate may have a significant impact to the region's sea turtle populations.

Long term sea turtle recovery will require efforts of the global community to decrease mortality and increase protection of habitats. International laws exist protecting sea turtles worldwide and $\mathrm{CBC}$ is now commonplace as a conservation strategy. Co-management is also another increasingly viable option (Campbell et al., 2009). However, keen attention must be paid to the ways in which communities are engaged and efforts must be made to deepen the understanding of officiators with regard to the needs and morays of stakeholders. Access to sea turtles is often regulated by social customs which help define their place in the community (Woodrum, 2010). As such, some $\mathrm{CBC}$ efforts around sea turtles and coastal habitat have aimed to include communities by acknowledging the traditions that link them and the turtles (Campbell, 2003). In recent years, traditional knowledge of sea turtles has been one such way to involve community members (Campbell, 2007). But often this is driven by economic incentives while community members' true needs and value are overlooked (Campbell et al., 2007).

Indigenous belief systems commonly incorporate taboos and totems that create environmental ethic behaviors by regulating an individual's interactions with the natural world (Shastri et al., 2002). In this study, we see how informal and judicial law, the sacred and the secular, may work together to aid the protection of wildlife. This relationship is seen throughout Africa, and Ghana in particular, by which traditional sacred sites already delineated by spiritual law afford already judicially protected species within them refuge (Wong and Sicotte, 2006; Diawuo and Issifu, 2015). Indeed, governments often exploit long-established sacred delineations to create parks and reserves since the areas are often the few patches of habitat left intact and are therefore identifiable as in the greatest need for judicial aid (Msuya and Kideghesho, 2009; Jimoh et al., 2012). However, these laws may not afford adequate enough protection, and enforcement may not be without significant complications. For example, the taboos protecting primates do not necessarily afford protection to the animals' habitat or animals beyond the habitat adjacent to the community (Saj et al., 2006). In Madagascar, food taboos regulate wildlife take locally, but state laws are widely known even as they may not be explicitly adhered to (Golden and Comaroff, 2015a). In a separate study, Golden and Comaroff (2015b) point out adherence to taboos is not uniform within cultural groups or even within communities in Madagascar specifically because these taboos are regulators of a very personal narrative. Resource use, therefore, must still be governed by judicial and informal law for conservation to be effective.

The existence of social taboos can ease cultural involvement to make laws more adaptable and enforcement more amenable to community members. Species-specific taboos are generally self-enforcing since penalties of sickness and even death are typically connected to the belief system (Colding and Folke, 1997; Diawuo and Issifu, 2015). In essence, the community has already been policing themselves therefore the judicial law can act as an official acknowledgment of these social restrictions. In Madagascar, Westerman and Gardner (2013) found that local communities around a marine reserve were more compliant with the restriction of use of the area after ceremonies venerating local ancestors were performed to consecrate the reserve. Several taboos which have their origin in an ancestral memory are already in place regarding use of the resources in the area. In Ghana, fishers in Ada and Winneba stated they are likely to release live turtles captured in nets which is in keeping with the judicial law and cultural tradition.

Judicial laws may validate informal institutions but modernization, colonialism, and immigration has been shown to aid in erosion of the social taboos that enable the laws. In terms of conservation, official regulation can aid in filling the cultural gap left by the loss of taboos that would otherwise protect animals and habitat. Key informants advised that Azizenya and Totope are changing in terms of the influx of new community members from other ethnic groups and they believe that this is diluting adherence to the taboo. Historically, colonization 
and Christianity have also caused cultural degradation in terms of retention of traditional belief structures across the African continent due to the vilification of these beliefs. Taboos against hunting gorillas afford protection to the Cross River gorilla, Gorilla gorilladiehli, in Cameroon, but Etiendem et al. (2011) warned this traditional protection is eroding and may disappear. Likewise, Anoliefo et al. (2003) found that urbanization and the adoption of Christianity had adverse effects on the adherence to taboos that protected sacred groves in certain communities in Nigeria. Also in Nigeria, Jimoh et al. (2012) found several social taboos that ultimately lend themselves to biodiversity conservation are under attack from the effects of colonization. Future studies on the sea turtle taboo in Ghana should include an analysis of adherence to it and any pressures that may drive its weakening. Further study of the continuity of the taboo, how those with current knowledge and adherence pass this on to the next generation, is also necessary. Lastly, a look at the ways taboo and education on the judicial law influence each other is needed to tease apart this relationship and minimize confounding factors.

Our connection to sea turtles is complex and inherently culturally driven. Expanding our understanding of these connections can only aid their conservation. While a good amount of literature exists on sea turtle taboos and social customs, further study of these traditions is necessary in locations like Ghana where community engagement in conservation efforts is needed. Interdisciplinary approaches to research like this study, which include the social sciences, can help assess the feasibility of existing conservation initiatives and set a more stable foundation for the development of new ones.

\section{REFERENCES}

Abayie-Boaten, A. (1998). Traditional conservation practices: Ghana's example. Inst. Afr. Stud. Res. Rev. 14, 42-51.

Agyekumhene, A., Armah, A. K., Allman, P., Lamptey, R., and Ababio, G. (2010). "Nesting ecology, hatching success, and protection of sea turtles in Ada Foah, Ghana," in Proceedings of the Twenty-Eighth Annual Symposium on Sea Turtle Biology and Conservation, NOAA Technical Memorandum. NOAA NMFSSEFSC-640, eds J. Blumenthal, A. Panagopoulou, and A. F. Rees? (Miami, FL: U.S. Department of Commerce), 134.

Allman, P., and Armah, A. K. (2008). "Establishing a sea turtle tagging and conservation program in Ghana," in Proceedings of the TwentyEighth Annual Symposium on Sea Turtle Biology and Conservation, NOAA TechnicalMemorandum. NOAA NMFS-SEFSC-602, eds K. Dean and M. López-Castro (Miami, FL: U.S. Department of Commerce), 72.

Allman, P., Barbour, D., and Agyekumhene, A. (2015). Loggerhead sea turtle nesting activity in Ghana. Afr. Sea Turtle Newsl. 3, 13-15.

Anoliefo, G., Isikhuemhen, O., and Ochije, N. (2003). Environmental implications of the erosion of cultural taboo practices in Awka-South local government area of Anambra State, Nigeria: 1. Forests, trees, and water resource preservation. J. Agric. Environ. Ethics 16, 281-296. doi: 10.1023/A:10236801 17717

Arhin, S. (2008). Complementing legislation: the role of cultural practices in the conservation of wildlife-examples from Ghana. J. Anim. Law 4, 93-98.

Armah, A. K., Darpaah, G. A., Wiafe, G., Adomako, J., Quartey, S. Q., Abotchie, C. E., et al. (1998). "Traditional and modern perspectives in marine turtle conservation in Ghana," in Proceedings of the Third UNESCO MAB Regional Seminar on Biosphere Reserves for Biodiversity Conservation and Sustainable Development in Anglophone Africa, ed D. S. Amlalo, L. D. Atsiatorme, and C. Fiati (Cape Coast: Ghana EPA), 80-87.

\section{ETHICS STATEMENT}

This study was carried out in accordance with the recommendation of the Institutional Review Board (IRB) at Florida Gulf Coast University, with written informed consent from all subjects (IRB \#2010-59)

\section{AUTHOR CONTRIBUTIONS}

PA conceptualized the research project and directed 20+ students that conducted the interviews. PA also provided oversight to the implementation of the project and then assisted with data analysis and a significant amount of writing and editing. LA finalized the interview questionnaires and helped conduct the study. LA also assisted with data analysis and wrote most of the manuscript draft. AA assisted with the conceptualization of the project and was able to lead the project in the field by coordinating fishermen and translators. AA wrote small portions of the manuscript but provided important review and editorial adjustments.

\section{ACKNOWLEDGMENTS}

The authors would like to thank the fishers, elders, decision makers, and chiefs of Akwidaa, Winneba, Azizenya, and Totope for speaking to the researchers about their culture and knowledge of sea turtles. We also recognize students enrolled in the 2010 and 2012 Ghana Research Program at FGCU for helping collect data for this project. We also appreciate the assistance provided by the Wildlife Division of the Ghana Forestry Commission.

Begossi, A. (1992). Food taboos at Búzios Island (Brazil): their significance and relation to folk medicine. J. Ethnobiol. 12, 117-139.

Bjorndal, K. A., and Jackson, J. B. C. (2003). "Roles of sea turtles in marine ecosystems: reconstructing the past," in The Biology of Sea Turtles Vol. 2, eds P. L. Lutz, J. A. Musick, and J. Wyneken (Boca Raton, FL: CRC Press), 259-273.

Bouchard, S. S., and Bjorndal, K. A. (2000). Sea turtles as biological transporters of nutrients and energy from marine to terrestrial ecosystems. Ecology 81, 2305-2313. doi: 10.1890/0012-9658(2000)081[2305:STABTO]2.0.CO;2

Campbell, L. M. (2003). Challenges to inter-disciplinary research: perspectives of a social scientist. Mar. Turtle Newsl. 100, 28-32.

Campbell, L. M. (2007). Local conservation practice and global discourse: a political ecology of sea turtle conservation. Ann. Assoc. Am. Geogr. 97, 313-334. doi: 10.1111/j.1467-8306.2007.00538.x

Campbell, L. M., Haalboom, B. J., and Trow, J. (2007). Sustainability of community-based conservation: sea turtle egg harvesting in Ostional (Costa Rica) ten years later. Environ. Conserv. 34, 122-131. doi: 10.1017/S0376892907003840

Campbell, L. M., Silver, J. J., Gray, N., Ranger, S., Broderick, A., Fisher, T., et al. (2009). Co-management of sea turtle fisheries: biogeography versus geopolitics. Mar. Policy 33, 137-145. doi: 10.1016/j.marpol.2008. 05.005

Campbell, M. O. (2005). Sacred groves for forest conservation in Ghana's coastal savannahs: assessing ecological and social dimensions. Singap. J. Trop. Geogr. 26, 151-169. doi: 10.1111/j.0129-7619.2005.00211.x

Colding, J., and Folke, C. (1997). The relations among threatened species, their protection, and taboos. Conserv. Ecol. 1:6. doi: 10.5751/ES-00018-010106

Colding, J., and Folke, C. (2001). Social taboos: "invisible" systems of local resource management and biological conservation. Ecol. Appl. 11, 584-600. doi: 10.2307/3060911 
Creswell, J. W. (2013). Qualitative, Quantitative, and Mixed Methods Approaches. London: Sage Publishing.

Darkwa, S., and Smardon, R. (2010). Ecosystem restoration: evaluating local knowledge and management systems of fishermen in Fosu Lagoon, Ghana. Environ. Pract. 12, 202-213. doi: 10.1017/S1466046610000256

Diawuo, F., and Issifu, A. K. (2015). Exploring the African traditional belief systems in natural resource conservation and management in Ghana. J. Pan Afr. Stud. $8,115-131$.

Etiendem, D., Hens, L., and Pereboom, Z. (2011). Traditional knowledge systems and the conservation of Cross River gorillas: a case study of Bechati, Fossimondi, Besali, Cameroon. Ecol. Soc. 16:22. doi: 10.5751/ES-04182-160322

Freud, S. (1913). Totem and Taboo: Resemblances Between the Mental Lives of Savages and Neurotics. Boston, MA: Beacon Press.

Gocking, R. S. (2005). The History of Ghana. Westport, CT: Greenwood Press.

Golden, C. D., and Comaroff, J. (2015a). Effects of social change on wildlife consumption taboos in northeastern Madagascar. Ecol. Soc. 20:41. doi: 10.5751/ES-07589-200241

Golden, C. D., and Comaroff, J. (2015b). The human health and conservation relevance of food taboos in northeastern Madagascar. Ecol. Soc. 20:42. doi: 10.5751/ES-07590-200242

Houghton, J. D. R., Doyle, T. K., Wilson, M. W., Davenport, J., and Hays, G. C. (2006). Jellyfish aggregations and leatherback turtle foraging patterns in a temperate coastal environment. Ecology 87, 1967-1972. doi: 10.1890/00129658(2006)87[1967:JAALTF]2.0.CO;2

Hulme, D., and Murphree, M. (1999). Communities, wildlife and the 'new conservation' in Africa. J. Int. Dev. 11, 11-285. doi: 10.1002/(SICI)10991328(199903/04) 11:2<277::AID-JID582>3.0.CO;2-T

Jimoh, S. O., Ikyaagba, E. T., Alarape, A. A., Obioha, E. E., and Adeyemi, A. A. (2012). The role of traditional laws and taboos in wildlife conservation in the Oban Hill sector of Cross River National Park (CRNP), Nigeria. J. Hum. Ecol. $39,209-219$.

Johannes, R. E. (1978). Traditional marine conservation methods in Oceania. Annu. Rev. Ecol. Evol. Syst. 9, 349-364. doi: 10.1146/annurev.es.09. 110178.002025

Kellert, S. R., Mehta, J. N., Ebbin, S. A., and Lichtenfeld, L. L. (2000). Community natural resource management: promise rhetoric and reality. Soc. Nat. Resour. 13, 705-715. doi: 10.1080/089419200750035575

Kideghesho, J. R. (2008). Co-existence between the traditional societies and wildlife in western Serengeti, Tanzania: its relevancy in the contemporary wildlife conservation efforts. Conserv. Biodivers. 17, 1861-1881. doi: 10.1007/s10531-007-9306-Z

Leon, Y. M., and Bjorndal, K. A. (2002). Selective feeding in the hawksbill turtle, an important predator in coral reef ecosystems. Mar. Ecol. Prog. Ser. 245, 249-258. doi: $10.3354 /$ meps 245249

Lynam, C. P., Gibbons, M. J., Axelsen, B. E., Sparks, C. A. J., Coetzee, J., Heywood, B. G., et al. (2006). Jellyfish overtake fish in a heavily fished ecosystem. Curr. Biol. 16, R492-R493. doi: 10.1016/j.cub.2006.06.018

McShane, T. O., and Wells, M. P. (2004). Getting Biodiversity Projects to Work: Towards More Effective Conservation and Development. Chichester: Columbia University Press.

Meylan, A. (1988). Spongivory in hawksbill turtles: a diet of glass. Science 239, 393-395. doi: 10.1126/science. 239.4838 .393

Morgan, R. C. (2007). Property of spirits: heredity and global value of sea turtles in Fiji. Hum. Organ. 66, 60-68. doi: 10.17730/humo.66.1.0w21624446650338

Msuya, T., and Kideghesho, J. R. (2009). The role of traditional management practices in enhancing sustainable use and conservation of medicinal plants in West Usambara Mountains, Tanzania. Trop. Cons. Sci. 2, 88-105. doi: $10.1177 / 194008290900200109$

Negi, C. S. (2010). The institution of taboo and the local resource management and conservation surrounding sacred natural sites in Uttarakhand, Central Himalaya. Int. J. Biodivers. Conserv. 2, 186-195.

Ntiamoa-Baidu, Y. (1991). Conservation of coastal lagoons in Ghana: the traditional approach. Landsc. Urban Plan. 20, 41-46. doi: 10.1016/0169-2046(91)90089-5

Ostrom, E. (1990). Governing the Commons. The Evolution of Institutions for Collective Action. Cambridge, UK: Cambridge University Press.
Peterson, R., Russell, D., West, P., and Brosius, J. (2010). Seeing (and doing) conservation through cultural lenses. Environ. Manage. 45, 5-18. doi: 10.1007/s00267-008-9135-1

Posner, R. A., and Rasmusen, E. B. (1999). Creating and enforcing norms, with special reference to sanctions. Int. Rev. Law Econ. 19, 369-382. doi: 10.1016/S0144-8188(99)00013-7

Riley, E. P. (2010). The importance of human-macaque folklore for conservation in Lore Lindu National Park, Sulawesi, Indonesia. Oryx 44, 235-240. doi: $10.1017 /$ S0030605309990925

Roe, D., Nelson, F., and Sandbrook, C. (2009). "Community involvement in natural resources management in Africa - regional overviews," in Community Management of Natural Resources in Africa: Impacts, Experiences, and Future Directions, eds D. Roe, F. Nelson, and C. Sandbrook (London: International Institute for Environment and Development), 13-54.

Saj, T. L., Mather, S. C., and Sicotte, P. (2006). Traditional taboos in biological conservation: the case of Colobus vellerosus at the BoabengFiema Monkey Sanctuary, Central Ghana. Soc. Sci. Inform. 45, 285-310. doi: $10.1177 / 0539018406063644$

Schneller, A. J. (2008). Environmental service learning: outcomes of innovative pedagogy in Baja California Sur, Mexico. Environ. Educ. Res. 14, 291-307. doi: $10.1080 / 13504620802192418$

Senko, J., Schneller, A. J., Solis, J., Ollervides, F., and Nichols, W. J. (2011). People helping turtles, turtles helping people: understanding resident attitudes towards sea turtle conservation and opportunities for enhanced community participation in Bahia Magdalena, Mexico. Ocean Coast Manage. 54, 148-157. doi: 10.1016/j.ocecoaman.2010.10.030

Shastri, C. M., Bhat, D. M., Nagaraja, B. C., Murali, K. S., and Ravindranath, N. H. (2002). Tree species diversity in a village ecosystem in Uttara Kannada district in Western Ghats, Karnatka. Curr. Sci. 82, 1080-1084.

Shirley, M. H., Oduro, W. E., and Yaokokore-Beiboro, H. (2009). Conservation and status of crocodiles in Ghana and Côte d'Ivoire, West Africa. Oryx 43, 1-10. doi: 10.1017/S0030605309001586

Silverman, D. (2006). Interpreting Qualitative Analysis: Methods for Analyzing Talk, Text, and Interaction. London: Sage Publishing.

Tengo, M., Johansson, K., Rakotondrasoa, F., Lundberg, J., Andriamaherilala, J., Rakotoarisoa, J., Elmqvist, T., et al. (2007). Taboos and forest governance: informal protection of hot spot dry forest in southern Madagascar. AMBIO 36, 683-691. doi: 10.1579/0044-7447(2007)36[683:TAFGIP]2.0.CO;2

Uyeda, L. T., Iskandar, E., Purbatrapsila, A., Pamungkas, J., Wirsing, A., and Kyes, R. (2014). The role of traditional beliefs in conservation of herpetofauna in Banten, Inonesia. Oryx 50, 296-301. doi: 10.1017/S0030605314000623

Westerman, K., and Gardner, C. J. (2013). Adoption of socio-cultural norms to increase community compliance in permanent marine reserves in southwest Madagascar. Conserv. Evid. 10, 4-9.

Western, D. (1994). "Ecosystem conservation and rural development," in Natural Connections. Perspectives in Community-based Conservation, eds D. Western and R. M. Wright (Washington, DC: Island Press), 15-52.

Western, D., and Wright, R. M. (1994). Natural Connections. Perspectives in Community-based Conservation. Washington, DC: Island Press.

Wong, S. N. P., and Sicotte, P. (2006). Population size and density of Colobus vellerosus at the Boabeng-Fiema Monkey Sanctuary and surrounding forest fragments in Ghana. Am. J. Primatol. 68, 465-476. doi: 10.1002/ajp.20242

Woodrum, R. (2010). Forbidden sea turtles: traditional laws pertaining to sea turtle consumption in Polynesia. Conserv. Soc. 8, 84-97. doi: $10.4103 / 0972-4923.62669$

Conflict of Interest Statement: The authors declare that the research was conducted in the absence of any commercial or financial relationships that could be construed as a potential conflict of interest.

Copyright (๑) 2017 Alexander, Agyekumhene and Allman. This is an open-access article distributed under the terms of the Creative Commons Attribution License (CC $B Y$ ). The use, distribution or reproduction in other forums is permitted, provided the original author(s) or licensor are credited and that the original publication in this journal is cited, in accordance with accepted academic practice. No use, distribution or reproduction is permitted which does not comply with these terms. 